\title{
Impact of Firm Size on Capital Budgeting Techniques: An Empirical Study of Textile Firms in Pakistan
}

\author{
Muhammad Arslan \\ M.Phil (MS) \\ Bahria University Islamabad, Pakistan \\ Email: MuhammadArslan73@gmail.com \\ Rashid Zaman \\ M.Phil (MS) \\ Bahria University Islamabad, Pakistan \\ Dr Muhammad Ayub Sidiqui \\ Associate Professor \\ Bahria University Islamabad, Pakistan
}

\begin{abstract}
s
This study examines the type of capital budgeting methods used by textile firms in Pakistan and impact of firm size on these methods. This study also investigates the relationship between the total assets of the firm and annual turnover of the firm according to primary capital budgeting technique used. Questionnaire method is used as a source of gathering primary data. SPSS is used as tool for analysis of data. Cross tabulation is applied on each variable. Chi square test is also applied to investigate the relationship between total assets of firm and total turnover of the firm according to primary capital budgeting technique used. Findings of this study reveal that net present value method and internal rate of return are two mostly used methods. Findings also show that there is no relationship between the total assets of the firms and turnover of the firm according to capital budgeting technique used by firms. These results are well supported by the literature.
\end{abstract}

Keywords: Net Present Value, Chi Square, Pakistan

\section{Introduction}

In today's competitive business environment long term capital investments have become a major critical issue. And organizations are in a process to understand which capital budgeting technique is suitable for them for survival. This is reason which gives importance to capital investment decision because the creation of shareholders wealth is the aim of an organization. Due to these reasons, it is important to investigate the capital budgeting practices that are mostly used by organization for making capital investment decisions. Capital budgeting is highly important because the decisions that are made involve the direction and opportunity and also for future growth of the organization.

In traditional methods that were used for capital investment decisions by a number of organizations, net present value method is one, although this method has its own limitations. For example, when the interest rates are uncertain it is not clear to what discount rate can be used. This is troublesome because with increase and decrease of discount rates NPV can also be decreased and increased. In a lot of cooperate finance books theoretically NPV is considered sound and suggested tool. And every investor chooses the project if the NPV of that project is positive. For maximizing economic traditions NPV is considered as brick because in a building bricks are base for it.

It is proven by many scholars that the shareholders wealth increase to only that extent at which there comes increase in NPV value. With the idea of discounting, one unit of currency today is more valuable than one unit of currency tomorrow. This paper investigates type of capital budgeting evaluation techniques that were used by textile firms in Pakistan. Paper also investigates the relationship between size of the firm and the type of capital budgeting evaluation techniques used. The size of the firm determines by the magnitude of turnover and assets of the firm. Section 2 deals with the literature and previous studies done on this area. It also deals with the methods used in previous studies. Section 3 deals with research design and methodology. Next section deals with the results and discussions. In section 5 deals with conclusion and area for future research.

\section{Literature Review}

The process of acquiring a long term venture or to build a new plant for business is called capital budgeting. Capital budgeting is known as investment appraisal. There are required big amount of funds for capital budgeting (Holmes, 1998). Once an investment proposal starts there incurs a big cost on it and it is not possible to ignore this cost and the reversal of project is also difficult (Holmes, 1998). Opportunities of investment that can produce or give benefit for more than one year are called capital investments (Peterson \& Fabozzi, 2002). 
Capital budgeting is also defined as the best option of financing for the long term investments decisions (Stenzel, 2003). Brewer, Garrison and Noreen (2005) further define capital budgeting as an investment analysis done by managers to determine which proposal has the best return in future cash flows. Investments are the options of financing in the long term assets. According to Peterson and Fabozzi (2002), the capital budgeting process consists of Investment screening and selection, Capital budget proposal, Budgeting approval and authorization. Capital budgeting is vital, because if it is not properly planned, these investments could have disastrous financial and cash-flow implications(Du tout \& Pienaar, 2005; Johnson, 1999).

There are five capital budgeting decision criteria, namely net present value (NPV), internal rate of return (IRR), payback period (PBP), modified IRR (MIRR) and Profitability index (PI) (E. F. Brigham \& Ehrhardt, 2005).

\section{Capital Budgeting Decision Criteria}

NPV is aligned with the goal of maximizing a shareholder wealth; consider the timing of these cash flows and also use of relevant cash flows. In NPV the future cash flows are discounted and if NPV is positive then the project will be acceptable (Els, 2010). If there are more than one project then that project should be accepted which has higher NPV (Drury, 2004). In a survey on 268 U.S. firms the internal rate of return was the mostly used method of that time (Gitman \& Forrester, 1977). A similar survey was conducted for large U.S. firms which have also similar results (Scott \& Petty, 1984). A survey that was conducted among companies that were existing in Malaysia, Hong Kong and Singapore in 1985 Payback period method was the mostly used primary method for evaluating and ranking projects (Wong, Farragher, \& Leung, 1987). A survey in 1992, 58 large firms of the Fortune 500 and 26 small firms of Forbes 200; DCF methods are used by most of firms, although percentage of these for the large firm is $88 \%$ (NPV) and 91\% (IRR) and percentage for small firms are 65\% and 54\% respectively (Trahan \& Gitman, 1995). Among North American and Western European companies the IRR, NPV and PBP methods are most popular methods (Brounen, 2004; Graham \& Harvey, 2001).

Correia et al. (2001) and others (Brigham, Ehrhardt, 2005, p. 360; Horngren et al., 2003, p. 720; Garisson and Noreen, 2000, p. 677) state the advantages of NPV as follows: time value of money concept; all cash flows; showing the risk associated with all future cash flows; and providing more reliable information than any of the other decision criteria because absolute values are used. According to finance theory and based on above advantages NPV method is considered as best method. Besides of some organizations in Canada all other are using NPV method as base method (Karim, Geoffrey, \& Teresa, 2010). Because the IRR gives value of investment in percentages the manager considers it attractive because due to this the comparison becomes easy between the projects(Cheng, 1994). Other authors (Baldwin \& Clark, 1994; Hayes \& Garvin, 1982) argue that the DCF methods focus on measurable effects, and are therefore biased towards short-termism. However, we believe that the use of DCF methods lead to more long term behavior than the use of payback and other accounting ratios in capital budgeting.

\section{Pay Back Method}

It is very simple method. It gives the accurate time of returning the amount. The project should be accepted your projected payback time (PB) is equal to/less than the time required by the organization (Brigham, 1988). Payback is the time period in which the initial cash outflows will be recovered from the sum of each year's cash inflows (Peterson \& Fabozzi, 2002). If the time period of project is equal or less than the cut off period then the project should be accepted and if this time period exceeds the cutoff period then project should be rejected.

\section{Internal Rate of Return (IRR)}

With the initial investment of a project; it gives present value of cash flows that discount rate is called internal rate of return. When IRR exceeds project cost of capital then that project will accepted (Brigham, 1988). According to Maher,et.al., (1997), McWatters, et.al. (2001) the internal rate of return is that discounted rate at which the presented value of projected future cash flows calculated for each project, equal to present value of initial investment and it causes the net present value equal to zero. IRR and NPV are best but conflicting results arise when we do ranking of mutually exclusive projects. When time and cash flows of projects differ with one another then conflicts arises. If IRR is less than the required rate of return then project must be rejected because it will give the negative NPV.

\section{Modified Internal Rate of Return (MIRR)}

MIRR considers better than IRR because in it we use weighted average cost of capital and from this it gives more accurate results than IRR (Brigham, 1988).

\section{Profitability Index}

The profitability index is used to evaluate different projects. It gives per dollar cost of present value of benefits. Project is considered to accept if Profitability index is greater and equal to 1(Brigham, 1988). PI is defined as the change in the net projected future cash inflows, discounting back to the present value by using the required rate of return, and dividing the sum of the discounted cash inflows by the cost of the initial investment 
(Peterson \& Fabozzi, 2002). If the PI is equal to one, then the NPV is equal to zero. Therefore, if the NPV is positive, the PI will be more than one, but if the NPV is negative, the PI will be less than one.

Capital Budgeting Process

Capital budgeting process consist of these steps (a) establishing goals, (b) developing strategies, (c) Searching for investment opportunities, (d) evaluating investment opportunities, (e) selecting the investments, (f) implementing, $(\mathrm{g})$ monitoring the various project, $(\mathrm{h})$ conducting a post audit (Seitz \& Ellison, 2005).

Theoretical Framework

Independent Variable

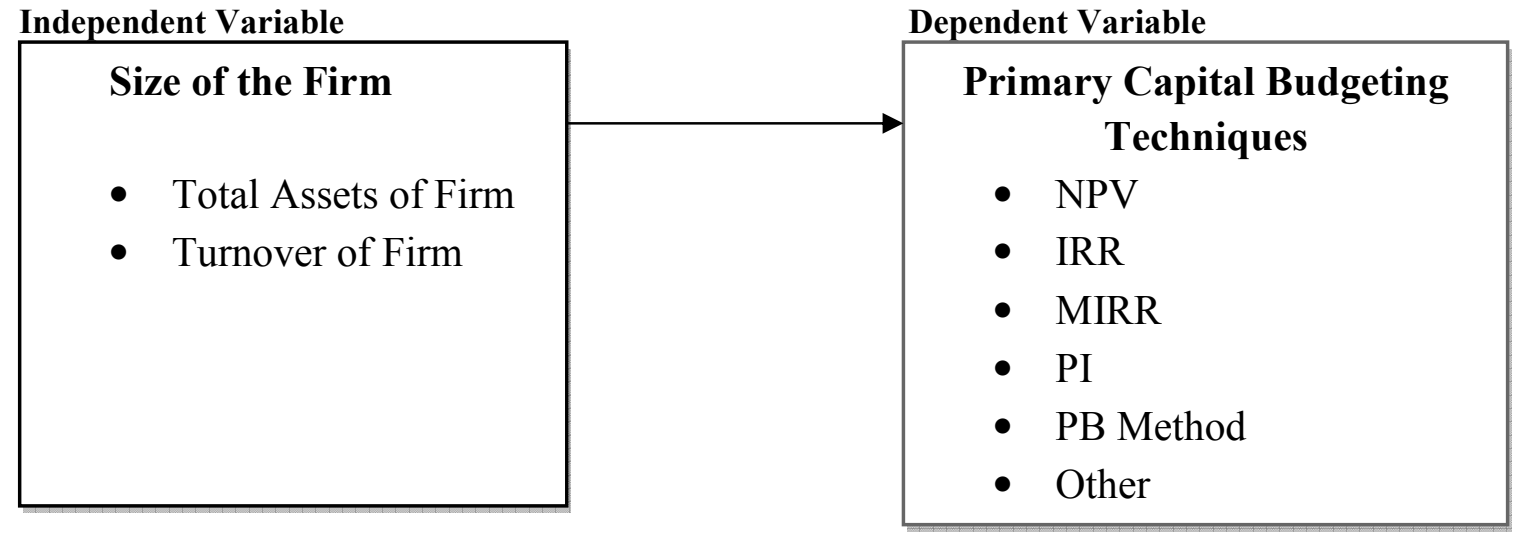

Adapt from (Bester, 2006).

Hypothesis

H10: There is no relation between total assets and primary capital budgeting techniques used by firms

H1: There is relation between total assets and primary capital budgeting techniques used by firms

H2o: There is no relation between total turnover and primary capital budgeting techniques used by firms

H2: There is relation between total turnover and primary capital budgeting techniques used by firms

Size of the firm is taken as independent variable and primary capital budgeting techniques used as dependent variables. Sales and total assets of the firm are taken as indicator of size of the firm and purpose is to find out the relationship between size of firm and primary capital budgeting techniques used by the firm.

\section{Research Design and Methodology \\ Secondary Data}

Secondary data refer to information that is collected by individuals, agencies and

institutions other than by the researcher Welman et.al.(2005). Secondary data is data which is collected for previous projects other than current project. The secondary data is necessary for analysis of capital budgeting evaluation techniques used by financial managers of the firms. A review of secondary data enabled the researcher to gain better understanding of theories and it is very helpful in making questionnaire. In this paper adapted questionnaire was used for collecting the information from the respondents (Bester, 2006).

\section{Primary Data}

Primary data is that data which is original data collected by researcher for conducting his own study Welman et.al.(2005). Researcher collects primary data in effort to answer his research questions. Primary research is undertaken when the information available from secondary sources is incorrect or inadequate. Primary data is depending upon population, sample frame and sample. In this paper primary data is collected through survey and questionnaire was used as a tool.

\section{Population}

Entire group of all people, events or things of interest that are under investigation of researcher is called population (Sekaran, 2004). From which events of groups, people the researcher wishes to find some characteristics that entire set of object and events is a called population (Bless \& Higson, 1995).In this study the population will consist of textile companies of Pakistan.

\section{Sample Frame}

A sample frame is a list of elements from which the actual sample is drawn (Blumberg, 2005). Sampling frame is a list of all units in the population from which list sample will be selected (Bryman \& Bell, 2007). The sample frame in this study will consist of the listed and non listed textile companies of Pakistan. Sample

A sample should represent the population of interests and it is collection of items, people etc which are under consideration (Collis \& Hussey, 2003). The sample should be representative of population. The sample in this study is textile companies which has high volume of production and high turnover. The reason for selecting this sector is that it invests millions Rs. on capital investment projects and it has a crucial impact in economies of 
country. Sample size for this study is 23 textile firms. Larger sample enables the researcher to draw more accurately results. But due to time constraints researcher can choose small sample. There are two types of sampling techniques available to a researcher, namely probability sampling, where the subject has a known chance of being selected from the population and non probability sampling, where the subject has an unknown chance of being selected from the population (Sekaran, 2004).

\section{Method}

In this paper SPSS was used as tool for analyzing data which was gathered through questionnaire. Cross tabulation were used for explaining the results of the survey. Chi square test was used for investigation of results and for checking the relationship between size of the firm and the primary technique used by firm. This Pearson's chi square is also test of independence. In some previous studies other methods like t-test or regression was used but in many studies chi square test was used and researchers relay on this test because of support of literature (Artikis, 1999; Chan, 2004; Gert \& Stefan, 2003; Kee \& Robbins, 1991).

\section{Results and Discussions}

Table 1: Distribution of respondents according to job title

\begin{tabular}{|l|l|l|}
\hline Job Title & Respondents & Percentage \\
\hline Manager & 9 & 39.1 \\
Officer & 7 & 30.4 \\
Executive & 7 & 30.4 \\
Total & 23 & 100.0 \\
\hline
\end{tabular}

Results of table1 shows that there are total 23 respondents and from these $39 \%$ are the having the manager level jobs, the officer and executive level personals have same percentage of $7 \%$.

Table 1.1: Distribution of respondents according to years of total experience

\begin{tabular}{|c|l|l|}
\hline Years of Experience & Respondents & Percentage \\
\hline $6-10 \mathrm{y}$ & 11 & 47.8 \\
$2-5 \mathrm{y}$ & 6 & 26.1 \\
$11-50 \mathrm{y}$ & 5 & 21.7 \\
$0-1 \mathrm{y}$ & 1 & 4.3 \\
Total & 23 & 100.0 \\
\hline
\end{tabular}

Table 1.1 results show that $47.8 \%$ respondents are having $6-10$ years of total experience and only $21.1 \%$ persons have total experience more than 10 years. About $21.7 \%$ respondents have more than 10 years of experience.

Table 1.2: Distribution of respondents according to years of total business experience

\begin{tabular}{|c|l|l|}
\hline Years of experience & Respondents & Percentage \\
\hline $2-5$ y & 14 & 60.9 \\
$0-1$ y & 5 & 21.7 \\
$6-10 \mathrm{Y}$ & 4 & 17.4 \\
Total & 23 & 100.0 \\
\hline
\end{tabular}

Table 1.2 shows that majority of respondents have business experience of 2-5 years. It means they have minimum knowledge of doing business. Only $17.4 \%$ respondents have $6-10$ years of experience.

Table 2: Distribution of respondents used capital budgeting technique for doing investment

\begin{tabular}{|ll|l|l|}
\hline Firms & Respondents & Percentage \\
\hline yes & 21 & 91.3 \\
No & 2 & 8.7 \\
Total & 23 & 100.0 \\
\hline
\end{tabular}

Table 2 shows that $91.3 \%$ of sampled firms are using capital budgeting technique for evaluating their investments and only $8.7 \%$ are not using capital budgeting technique. 
Table 2.1: Capital budgeting Calculation done by finance manager

\begin{tabular}{|c|l|l|}
\hline $\begin{array}{l}\text { Calculations done by } \\
\text { finance manager }\end{array}$ & Respondents & Percentage \\
\hline yes & 19 & 82.6 \\
No & 4 & 17.4 \\
Total & 23 & 100.0 \\
\hline
\end{tabular}

Table 2.1 results show that in majority of firms capital budgeting is done by financial manager which are using capital budgeting technique. Only $17.4 \%$ are not using the capital budgeting techniques done by financial manager.

Table 2.2 Type of capital budgeting technique used

\begin{tabular}{|ll|l|l|}
\hline $\begin{array}{l}\text { Type of capital budgeting technique } \\
\text { used }\end{array}$ & Respondents & Percentage \\
\hline & Net Present Value Method & 15 & 65.2 \\
& Internal Rate of Return & 4 & 17.4 \\
& Profitability Index & 2 & 8.7 \\
& other & 2 & 8.7 \\
& Total & 23 & 100.0 \\
\hline
\end{tabular}

Table 2.2 shows the type of capital budgeting used by firms. Results show that net present value is used by most of the firms and its percentage is $65.2 \%$. Second mostly used method is internal rate of return which has percentage of $17.4 \%$. These findings are consistent with the previous studies (Bester, 2006; Peterson \& Fabozzi, 2002; Suzette \& Howard, 2011). Profitability index and other method of investments have same percentage of $2 \%$.

Table 2.3 Primary choice for final decision of investment

\begin{tabular}{|l|l|l|}
\hline Primary choice of capital budgeting & Respondents & Percentage \\
\hline Net Present Value & 10 & 43.5 \\
Internal Rate of Return & 7 & 30.4 \\
Profitability Index & 2 & 8.7 \\
Other & 2 & 8.7 \\
Payback Period & 1 & 4.3 \\
Modified Internal Rate of Return & 1 & 4.3 \\
Total & 23 & 100.0 \\
\hline
\end{tabular}

Table 2.3 shows that net present value method are used by most of firms as primary choice for investing into projects. Internal rate of return are used by second most reliable method of capital budgeting. Previous studies also showed these results (Bester, 2006; Hogaboam \& Shook, 2004; Scott \& Petty, 1984; Suzette \& Howard, 2011).

Table 3 Book value of total assets

\begin{tabular}{|l|l|l|}
\hline Total assets & Respondents & Percentage \\
\hline Rs.10000001-30000000 & 10 & 43.5 \\
Rs.30000001-500000000 & 9 & 39.1 \\
Rs. 500000001- & 3 & 13.0 \\
1000000000 & 1 & 4.3 \\
Rs.1-10000000 & 23 & 100.0 \\
Total & & \\
\hline
\end{tabular}

Table 3 shows that book value of total assets of the respondents firms. From table it can be interpret that most of the respondent's lies between in category of 10000001-30000000. And their percentage is $43.5 \%$. About $39.1 \%$ have total assets of 30000001-50000000. Only $4.3 \%$ respondents lie between $1-10000000$. It means these are not enough large firms that can invest millions rupees on capital investments. 13\% respondents have total assets of more than 50 million rupee. 
Table 3.1 Rupee value of turnover per annum

\begin{tabular}{|l|l|l|}
\hline Turnover & Respondents & Percentage \\
\hline $1-3000000$ & 16 & 69.6 \\
$3000001-10000000$ & 4 & 17.4 \\
$10000001-30000000$ & 3 & 13.0 \\
Total & 23 & 100.0 \\
\hline
\end{tabular}

Table 3.1 shows the annual turnover of the sales. $69.6 \%$ respondents have turnover of $1-3$ million annually. $17.4 \%$ respondents have 3000001-10000000 turnover of sales volume.

Table 4 Chi Square test for Total assets of the firm according to primary capital budgeting technique used

\begin{tabular}{|c|c|c|c|c|c|}
\hline \multirow{2}{*}{$\begin{array}{l}\text { Primary } \\
\text { type } \\
\text { capital } \\
\text { budgeting } \\
\text { technique }\end{array}$} & \multicolumn{5}{|c|}{ Book value of total assets } \\
\hline & Rs. 1-10000000 & $\begin{array}{l}\text { Rs. } 10000001- \\
30000000\end{array}$ & $\begin{array}{l}\text { Rs.30000001- } \\
500000000\end{array}$ & $\begin{array}{l}\text { Rs. } 500000001- \\
1000000000\end{array}$ & Total \\
\hline NPV & 1 & 6 & 3 & 0 & 10 \\
\hline IRR & 0 & 2 & 3 & 2 & 7 \\
\hline PBP & 0 & 0 & 1 & 0 & 1 \\
\hline PI & 0 & 1 & 1 & 0 & 2 \\
\hline MIRR & 0 & 0 & 1 & 0 & 1 \\
\hline other & 0 & 1 & 0 & 1 & 2 \\
\hline Total & 1 & 10 & 9 & 3 & 23 \\
\hline
\end{tabular}

Pearson Chi Square $=11.383, \mathrm{df}=15, \mathrm{P}=.725$

From table 4 it can be interpret those respondents with total assets in category of RS. 1000000130000000 uses the net present value method frequently. There are $8.7 \%$ of the peoples that are not using any capital budgeting technique and they are using other methods of capital budgeting. By applying chi square test for total assets of the firm according to primary technique for capital budgeting, results shows that chi square value is 11.383 , df is 15 and p-value is 0.725 which is greater than 0.05 . It means that there is no significant relation exists between contrasting means exists. We reject the H1 hypotheses and accept the H1o hypotheses. These results were supported by previous researchers (Bester, 2006).

Table 4.1 Chi square test for turnover of the firm according Annual turnover of the firm

\begin{tabular}{|l|l|l|l|l|}
\hline \multirow{2}{*}{$\begin{array}{l}\text { Primary type } \\
\text { of capital } \\
\text { budgeting } \\
\text { technique }\end{array}$} & & Annual Turnover of the firm & \multicolumn{2}{l|}{} \\
\cline { 2 - 5 } & Rs. 1-3000000 & Rs. 3000001-10000000 & Rs.10000001-30000000 & Total \\
\hline NPV & 8 & 2 & 0 & 10 \\
IRR & 4 & 1 & 2 & 7 \\
PBP & 1 & 0 & 0 & 1 \\
PI & 1 & 1 & 0 & 2 \\
MIRR & 1 & 0 & 0 & 1 \\
Other & 1 & 0 & 1 & 2 \\
\hline Total & 16 & 4 & 3 & 23 \\
\hline
\end{tabular}

Pearson Chi square $=8.001, \mathrm{df}=10, \mathrm{P}=.628$

Results of table 4.1 it shows that firms having annual turnover of 1-3M, used net present value method. Results also show that net present value method and internal rate of return are two mostly used primary capital budgeting techniques. These results are consistent with previous studies (Peterson \& Fabozzi, 2002; Suzette \& Howard, 2011). Chi square value is 8.001 and df is 10 . P- Value is 0.628 which is greater than 0.05 . From pvalue it can be interpret that there is no significant relation exist between annual turnover of the firm and primary technique used by firm. We should accept the null hypothesis. So, H2 hypothesis is rejected and H2o is accepted. These results have previous literature support (Bester, 2006).

\section{Conclusion}

The findings of this study conclude that in sampled firms net present value method is used by most of the firms. Internal rate of return is second mostly used method. Profitability index and MIRR are in the sequence. The results of chi square tests show that there is no significant relation exists between the total assets of the firm and 
turnover of the firm according to the primary technique used. Results are applied at $5 \%$ level of significance. Values of $\mathrm{p}$ are greater than $0.05 \%$, it means that null hypothesis should be accepted and alternative hypotheses should reject.

\section{References}

Artikis, P. G. (1999). A Capital Budgeting Stochastic Simulation Model Applied in the Banking Industry. Managerial Finance, 25(8).

Baldwin, C. Y., \& Clark, K. B. (1994). Capital Budgeting Systems and Capabilities investments In U.S. companies after Second world war. Business history rview, 73-109.

Bester, L. (2006). AN EMPIRICAL STUDY OF CAPITAL BUDGETING EVALUATION TECHNIQUES USED BY FIRMS IN THE NELSON MANDELA METROPOLE. Cost and Management Accounting, Nelson Mandela Metropolitan University, NELSON MANDELA METROPOLE.

Bless, C., \& Higson, C. S. (1995). Fundamentals of Social Research Methods: An African Perspective.

Blumberg, B. (2005). Business Research Methods. 2.

Brigham. (1988). Financial management: Theory and practice. 5.

Brigham, E. F., \& Ehrhardt, M. C. (2005). Financial management theory and practice. 11.

Brounen, D. (2004). Corporate finance in Europe: Confronting theory with practice. Financial Management, 33(4), 71-101.

Bryman, A., \& Bell, E. (2007). Business Research Methods,. (2).

Chan, Y.-C. 1. (2004). Use of Capital Budgeting Techniques and an Analytic Approach to Capital Investment Decisions in Canadian Municipal Governments. Public Budgeting \& Finance

Cheng, A. C. S. (1994). The aplicability and usage of IRR and NPV capital budgeting techniques. The Engineering Economist, 40(7), 10-36.

Collis, J., \& Hussey, R. (2003). Business Research. (2).

Drury, C. (2004). Management and cost accounting. 6, 389.

Du tout, J., M, \& Pienaar, A. (2005). A review of capital budgeting behavior of large south africans firms. Meditari Accountancy Research, 12(1), 19-27.

Els, G. (2010). Cooperate finance:Asouth african perspective. 151.

Gert, S., \& Stefan, S. o. (2003). Capital budgeting methods among Sweden's largest groupsof companies:The state of the art and a comparison with earlier studies. Production Economics, 84, 51-69.

Gitman, J. L., \& Forrester, J. R. (1977). A survey of capital budgeting techniques used by Major U.S. firms. financial Management, 6(3), 66-71.

Graham, R. J., \& Harvey, R. C. (2001). The theory and practice of corporate finance: Evidence from the field. Journal of Financial Economics, 60(2-3), 187-243.

Hayes, R. H., \& Garvin, D. A. (1982). Managing as If tomorrow matters. Harvard Business review, 60(3), 70-79.

Hogaboam, L. S., \& Shook. (2004). Capital Budgeting practices in U.S. forecasr product industry: A appraisal. Forecast Product Journal, 54(12), 149-158.

Holmes, P. (1998). Investment appraisal.

Johnson, H. (1999). Making capital Budgeting decisions: Maximizing the value of firm.

Karim, B., Geoffrey, M. G., \& Teresa, M. (2010). Improved capital budgeting decision making: Evidence from Canada. Management Decision, 48(2), 225-247.

Kee, R., \& Robbins, W. (1991). Capital Budgeting In The Public Sector: A Comparative Analysis. Journal of Managerial Issues, 3(3), 288-302.

Peterson, P., \& Fabozzi, F. (2002). Capital Budgeting Theory and practice. 10, 9.

Scott, F. D., \& Petty, W. (1984). Capital budgeting practices in large Americans Firms: A retrospective Analysis and Synthesis. Financial Review, 121-122.

Seitz, N., \& Ellison, M. (2005). Capital Budgeting and long term financing decisions. 4.

Sekaran, H. (2004). Research Methods for Business: A Skill-building Approach. Wiley, 3.

Suzette, v., \& Howard, C. (2011). Perspective of capital Budgeting in South African Motor Manufacturing inndustry. Meditari Accountancy Reseach, 19(1/2), 75-93.

Trahan, A. E., \& Gitman, J. L. (1995). Bridging the theory-practice gap in corporate finance: A survey of chief financial officers. The Quarterly Review of Economics and Finance, 35(1), 73-87.

Welman, C., Kruger, F., \& Mitchel, B. (2005). Research Methodology. Oxford University Press, Cape Town, 3.

Wong, A. K., Farragher, J. C., \& Leung, R. K. (1987). Capital investment practices: A survey of large corporations in Malaysia, Singapore and Hong Kong. Asia-Pacific Journal of Management, 4(2), 112 123. 